\title{
Teaching Active Citizenship: A Companion to the Traditional Political Science Curriculum
}

Michael Smith, Emporia State University

The Honorable Bob Graham, United States Senate (Retired)

ABSTRACT The authors of this article advocate a new curriculum that can be applied to American government, introduction to political science, and state and local government courses. For the past half-century, high school and college general-education requirements have deemphasized civics, government, and political science. In response to the corresponding decrease in the nation's civic health, this proposal is based on three principles. First, teaching citizenship is different than teaching civics. Second, citizenship is taught most effectively by engagement in the "real world," with students completing projects that take them step by step through the policy-change process. Finally, the education and preparation of future high school government teachers needs to change to encourage them to teach their students the rights, responsibilities, and competencies of active citizenship.

The objects of this primary education...would be, [t]o give every citizen the information he [or she] needs;... [t] o understand his [or her] duties to...neighbors and country, and to discharge with competence the functions confided... by either;... [t] instruct the mass of our citizens in these, their rights, interests, and duties, and as men [and women] and as citizens."

-Thomas Jefferson

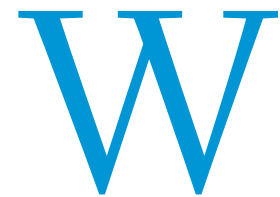

e have great hope that Americans will embrace a renaissance of citizenship. Anecdotal accounts and classroom stories fuel this hope. The National Conference on Civic Learning and Democratic Engagement (NCCLDE) documented numerous instances in which Americans band together to solve problems: many of us still volunteer to improve communities, join interest groups, take an interest in politics, and vote (NCCLDE 2012). Some schools even report that civics courses are beginning to reappear in the curriculum (Dalton 2012, 73). This article proposes a new curriculum of active citizenship.

In their book, America:The Owner's Manual, Bob Graham and Chris Hand proposed an active-citizenship-based curriculum that is based on achieving change on a local issue that students choose rather than lengthy deliberations and "town-hall meetings" about issues that may be of little interest to them (Graham and Hand 2009). The approach

Michael Smith is associate professor of political science at Emporia State University. He can be reached at msmith3@emporia.edu.

Bob Graham is a retired US senator and former Florida governor. He can be reached at Bob.Graham@grahamcos.com. is to coach students on the skills they need to affect policy change in a local issue about which they are passionate. This is a "bottom-up" curriculum in which students are challenged to begin their studies at the local or campus level by identifying ways that governments have an immediate impact on their own life. We further propose to teach students the skills needed to change these policies or to defend them against unwanted changes. We believe the evidence is clear: that teaching students the skills to get a speed bump installed on a local street or to have exposed insulation in public housing removed is the ideal introduction to teaching "higher-level" concepts (e.g., federalism).

Our proposed alternative for the integration of citizenship into a civics curriculum mimics the process to acquire competence in music, athletics, or other high-level aspirations. We use the piano as an example. The learner becomes interested through observing a parent, sibling, friend, or television personality execute the skill. Intrigued, the learner may begin to experience the skill by untutored experimentation-that is, banging on the keys. If intrigue advances to interest, the learner most likely will seek professional instruction. If interest leads to borderline mastery, the learner may desire to understand the theories behind the skill.

How would such a learn-by-doing approach apply to teaching federalism, for example? What follows is a lesson outline that demonstrates one way in which the same approach to learning the piano could be applied to a political science course. The introduction should be a narrative that provides a captivating human experience-for example, a film, a classroom presentation by an invited guest, or a case study. The most powerful lessons will closely parallel students' own life experiences. One example is a dangerous intersection near the school that requires federal and state funding to upgrade. A second 
example is today's complex and interlaced federal, state, and local joint efforts to establish a Common Core curriculum in $\mathrm{K}-12$ public schools. Most college students are recent alumni of these schools and may have younger siblings or friends still attending them. Others are nontraditional students with children of their own. Still others are future teachers with much at stake in the Common Core debates.

The learner would be "moved to the keyboard" through standard instruction in the origins, evolution, institutions, and consequences of federalism as a pattern for the organization of a large and diverse democratic society. The case study, or other form of introductory interest stimulation, would provide a tangible touchstone to better understand the history of federalism.

The professional instruction would focus on how a citizen deals with the practical complexities of federalism. Examples of questions that students may ask include: "I was almost run over at the intersection-to whom do I complain?" "How will the layers of government between me and the gurus of Common Core affect my ability and likelihood of being prepared for higher education or a career?" "How do I make the system work for me?" This instruction will prepare the learner for delving into deeper critical thinking about the theory of federalism. Discussion questions include: "Is this eighteenth-century concept capable of providing responsible
THE CIVICS CURRICULUM: DECLINE AND RENEWAL

Currently, we are experiencing the consequences of a long decline in citizenship: one that has afflicted our politics with incivility, intolerance, excessive partisanship, and gridlock. This has cascaded to cynicism, as Americans withdraw from a political system from which they have disconnected. Our proposal is based on Robert Putnam's “diminishing social capital” thesis (Putnam 2001). Stated simply, Americans are less likely to belong to civic organizations than were their grandparents, choosing instead to spend more time in activities at home or with informal groups. The result is a decrease in group membership and, therefore, less of the local, social capital that once undergirded participation in our electoral system (Campbell et al. 1960). Ultimately, this results in lower rates of voter turnout and participation, despite generally higher education levels. The problem is not confined to the United States, although cross-national studies that include the United States are difficult to find. Nevertheless, the 2010 Civic and Citizenship Education study of 39 countries (not including the United States) revealed similar concerns. The authors of that study found that "according to teachers, student participation in civic-related activities is relatively widespread but its focus is sports events and cultural activities" (Schulz et al. 2010).

\section{Following Niemi and Junn, Ehman, and Campbell, we argue that it is not only the number of classes that students take but also the methods and content that affect their acquisition of political knowledge, interest, and skills.}

government in the twenty-first century?" "What are today's primary challenges-and is federalism up to these?" "What are the alternatives to federalism?"

Throughout the process, it is important to remember that the skills required for superior performance in the concert hall or arena are not obtained solely in a classroom. A basketball team that spends the preseason in the coach's office learning the rules and strategies of the game but never practicing would almost certainly have a dismal record. Students should be required to undertake hands-on activities that are aimed at changing or enhancing the status quo. Can a student really convince an official with the power to do so to rebuild the dangerous intersection and save lives? If so, he or she deserves an A-plus and would have earned the admiration of President Jefferson.

To effectively reform civic education, we propose a renewed attention to both strains of American political culture, as described by Quentin Kidd (2011). On the one hand, we need to celebrate the civicduty orientation in our teaching, cultivating a belief that political participation is both rewarding and a responsibility. On the other hand, we also believe that attention to the self-interest model of political behavior is crucial; otherwise, students will leave class with a "naïve" idea of politics that sets them up for disillusionment later (Hibbing and Theiss-Morse 1996). We therefore propose that citizenship education shift from a formulaic, "nuts-and-bolts" approach to the institutions and processes of government to an approach favoring problem-solving skills that empower students to negotiate deep disagreements, values conflicts, and complex decisions as they persuade stakeholders and decision makers. We therefore propose this curriculum as a supplement to traditional political science lessons.
John Hibbing and Elizabeth Theiss-Morse see a cynical electorate. They argue that most Americans dislike political processes, preferring to participate in government only when absolutely necessary to avoid being "played for suckers" by self-serving politicians and interest groups (Hibbing and Theiss-Morse 2002, ch. 6). In their 1996 work, they stressed the need for better civic education to better prepare students for the realities of democratic governance (Hibbing and Theiss-Morse 1996). In particular, they emphasized the need to abandon "textbook" models in favor of teaching a more realistic view focused on the "barbarics" of politics: that is, the rough and tough deal making and quid pro quo that go into a successful mastery of politics. We agree and seek to develop that argument further. We also agree that "town-hall meetings" do not provide a promising solution, and our proposed curriculum is sharply different.

Earlier studies, including Langston and Jennings (1968), Jennings and Niemi (1974), and Smith (1989), revealed only modest effects of high school education on students' knowledge of, interest in, and participation in politics. However, Delli Carpini and Keeter found a stronger relationship, with education raising students' levels of political knowledge and participation $(1997,198)$. However, this happened against a backdrop of Americans' general withdrawal from politics since the 1950s, as later documented by Putnam (2001). The earlier studies mostly focus on whether students have taken civics courses, but Richard Niemi and Jane Junn described a more in-depth discussion of the teaching methods used (Niemi and Junn 1998). Even when controlling for variables such as a student's prior interest in politics, family background, and college plans, they still found meaningful effects. Specifically, the "amount and relevancy of course work," "variety of topics studied," and whether they "discussed current events in class" all had significant and positive effects on students' knowledge 
of politics (Niemi and Junn 1998, 134). Previously, Lee Ehman found that students learn civics more effectively if they are taught in an "open" classroom in which they had freedom to express their opinions and different points of view were allowed (Ehman 1980). David Campbell found similar results in a study of high school students (Campbell 2008). Following Niemi and Junn, Ehman, and Campbell, we argue that it is not only the number of classes that students take but also the methods and content that affect their acquisition of political knowledge, interest, and skills.

Finally, we are encouraged by the popularity of service learning on both high school and college campuses around the country, but our proposed curriculum is different. Service learning reflects one of the same priorities of our own program: learning outside of the classroom. However, our students report informally that service learning in many high school and college programs is focused more on helping charitable causes than on teaching the skills of democracy. Furthermore, service-learning programs such as Alternative Spring Break encourage students to travel (across town, across the country, or across the world) to help people in need. This is laudable but it is not the same as focusing on changes that affect students' own lives, in their own communities. Nevertheless, service learning has shown promise. The NCCLDE conducted a survey that found robust support for the idea across many demographic groups, including those most at risk for dropping out of high school (NCCLDE 2012).

\section{HOMEWORK ASSIGNMENTS AND PROJECTS}

A variant of our new curriculum has been used for several by years in an introduction to political science course at Emporia State University in Kansas. Emporia is a comprehensive state university featuring small class sizes, careful advising, and a nationally recognized teacher's college (Hartocollis 2005), all of which are major recruiting draws. It is not surprising that many of the students enrolled in the introductory course are future teachers. The university also has a small but highly successful political science program.

The project is designed as follows: in conjunction with the traditional curriculum, the America book by Graham and Hand is taught as a supplement. Throughout the semester, one-day lessons corresponding to each of the 10 chapters are interlaced with other class days that focus on a more traditional curriculum. Lessons from the book include the following:

- identifying a local or campus topic that is in the student's own self-interest

- finding and presenting credible research on the topic

- identifying decision makers and their self-interests and effectively persuading them

- identifying and mobilizing allies

- developing a news media strategy

- conducting a self-assessment

These lessons can be taught in as few as 10 days in a 16-week semester, leaving most of the time free for more traditional lessons in the discipline. Many of the lessons dovetail with a standard political science curriculum. Consider the following:

- The opening discussion about self-interest flows from a discussion of rational-choice theory, as do the discussions about the self-interest of decision makers and allies.

- The research chapter provides students with study tips for identifying credible sources and presenting research effectively.
- The chapter on public opinion fits with lessons about the proper interpretation of public-opinion polls. However, students should be encouraged to pursue Institutional Review Board approval before conducting their own surveys.

- The news-media exercise promotes a host of lessons about the role of the media in politics.

- Classic lessons on "how a bill becomes a law" fit with students' identification of the steps and levels of government they must master for successful projects.

- Finally, the entire book offers many lessons about the complexities of the federalist system as students learn how their topics of interest are affected by federal grants, state formulas, local ordinances, and so forth.

After each chapter has been covered in class, students are given one week to write a two- or three-page assignment, which is described at the end of the corresponding chapter. The project culminates in a five-page report of the results during final-exams week. Students are encouraged and rewarded for a completed policy-change project, but credit also is offered for projects that make solid but incomplete progress. These projects may lead to successful outcomes if the students choose to pursue them on their own after the end of the semester.

Typically, a few students complete outstanding projects that culminate in policy change, earning an "A." A few more projects are almost complete by the end of the semester. Other students learn valuable lessons and make credible progress toward a result but do not complete the policy changes. These projects usually earn "B" and " $\mathrm{C}$ " grades. Special consideration is given to projects that are incomplete due to circumstances beyond a student's control, such as a proposal for a new school program that is first developed during a summer semester. The only way that incomplete projects can earn an " $A$ " is if they are ready for implementation, with the support of decision makers and allies, a timetable, and detailed plans to execute the project as soon the policy window opens (which the student also must specify).

\section{TOPICS}

Students choose their own project topics and the professor only rarely exercises veto power. There is a natural tendency for students' projects to fall into the following broad areas:

- Curricular change at the university: examples include more foreignlanguage courses and more affordable textbooks in generaleducation courses.

- Noncurricular change at the university: for example, better facilities for all of the university sports teams, intramural leagues, and student sports clubs, not only the men's basketball and football teams.

- Local traffic-safety issues for automobiles: examples include stop signs at unregulated intersections and better enforcement of speed limits near schools.

- Local traffic-safety issues for bicycles and pedestrians: examples include bike lanes and paths, sidewalk repair, and patrolled crosswalks.

- Issues in a K-12 school district (i.e., the school from which a traditional-aged student recently graduated, the school attended by children of a nontraditional student, or the school in which a future K-12 teacher hopes to find employment): examples include antibullying policies, reinstatement of projects or classes cancelled due to budget cuts, and issues regarding school athletic teams. 
- Americans with Disabilities Act (ADA) compliance: examples include issues in local apartment complexes, campus buildings, and campus sports facilities.

- Housing issues: examples usually include code enforcement for rental housing near campus.

\section{GRADING AND ASSESSMENT}

Course objectives are presented to students on the first day of class, enumerated at the top of the syllabus. The projects are most relevant to the first and last objectives, whereas the others relate to the more traditional lessons still taught during the course. This course is an introduction to political science course, not American government; however, the supplemental curriculum can be adapted for several different courses. The course objectives are as follows:

- Learn the practical political skills necessary to participate in democratic governance.

- Discuss selected philosophers from the canon of political theory whose ideas are relevant today.

- Introduce the assumptions, methods, and results of selected, recent political science research.

- Compare and contrast the electoral and lawmaking systems of several different countries.

- Promote deliberation and discussion of political topics that affect students' lives.

Clearly, the project relates primarily to the first objective, but it is relevant to the last two as well. A series of short homework assignments from the book culminates in a final project. To clarify grading expectations, the final-project rubric is given to students at the beginning of the semester (see the appendix). The rubric provides a quantitative, intersubjectively verifiable means of assessing student performance. Students appreciate the clarification of expectations well before the assignment due dates. time-consuming topic so as not to jeopardize their grade point average or compromise study time for other classes. Furthermore, of all of the success stories described, not one was completed by a political science major. Instead, success-story students run the gamut of majors, with a particular emphasis on those studying to be K-12 teachers. Political science majors often aim too high in their ambitions for policy change. They tend to enjoy the projects, but some find it difficult to break away from the national issues that naturally draw their attention to refocus on local questions, such as campus smoking policies, school crossing guards, and bike lanes. Conversely, future K-12 teachers may have a strong pull toward the "hands-on" method of teaching described in this article.

One student enlisted the help of a local fire marshal and a state representative to persuade the Kansas Department of Transportation (DOT) to lower the speed limit on a dangerous stretch of highway where a friend had been killed. Similar to all successful projects, this one began with the student's own life experience: the death of his friend. His passion for the issue impelled him to learn the workings of Kansas state government. At first, he could not identify his state representative, much less how the legislature functioned. In the end, he had mastered more sophisticated lessons including the importance of the committee system-he had enlisted a state representative on the transportation committee as a "target" who became an ally. The student also studied oversight: the state representative was able to persuade officials at the Kansas DOT, the final target, to lower the speed limit without having to pass new legislation. Furthermore, the student studied the role of alliance building-as a first responder to accidents along that highway, the local fire marshal was happy to help. Working on an issue about which he was passionate, this student learned the policy-making process, made key allies, and then successfully pressed for change.

An online student organized his neighbors as allies through door-to-door canvassing, town-hall meetings, and letter-writing campaigns. His goal was to petition the Salina, Kansas, municipal

\section{The typical success story is a student who begins the class at the B level: that is, generally curious and willing to do the work but sometimes bored and unmotivated in traditional classes, particularly when the curriculum seems unrelated to the "real world." These students also are more willing to take on big projects with the inherent promise of success balanced by the risk of disappointment.}

\section{SUCCESS STORIES: NOT THE TRADITIONAL "A" STUDENT}

As discussed previously, most students make some progress on their projects and learn valuable lessons but do not complete their work, earning "B" and "C" grades. However, some students have completed astonishing work, as described in the following examples. It is interesting that the most remarkable projects are not always completed by stereotypical "straight-A" or "honors" students. The typical success story is a student who begins the class at the B level: that is, generally curious and willing to do the work but sometimes bored and unmotivated in traditional classes, particularly when the curriculum seems unrelated to the "real world." These students also are more willing to take on big projects with the inherent promise of success balanced by the risk of disappointment. Stereotypical "A" students are more likely to choose a safer, smaller, less government to replace aging water lines in his neighborhood. Because the student blamed the bad water for ruining his appliances, he had a clear self-interest in the project. While researching his problem, he discovered that the city was planning to replace newer, more intact water lines in a wealthier part of town before getting around to his neighborhood. His response was to organize his neighbors as allies and to identify key targets by researching the city government: the city manager, the water-department director, and the mayor. The student's project was successful: new water lines have since been installed in his neighborhood.

As a result of another student's project, a local apartment complex became disabled-accessible. The student had attempted an earlier project (i.e., reducing paper wasted in local junk mail) but was unsuccessful. After a mid-semester course correction, she realized that a better project would be rooted in something she 
cared about: her own neighbors. She had befriended several of them, including an older disabled resident and a young family that had a child who uses a wheelchair. She watched them struggle to and from a narrow handicapped parking space, around the entire building, and enter through the back because the front entrance had no curb cuts. She started locally by asking the apartment manager to make the needed changes, but he refused. She had learned about the ADA in high school, and now she found an opportunity to use that knowledge. She identified a key target: the board of directors for the out-of-state realty company that owned the complex. During her project, the student found herself on a conference call with the board, which thanked her and promised quick action. One board member became an ally, telling the student that he cared deeply about this issue because his own mother is disabled. Since then, a new apartment manager was hired who made the complex ADA-compliant.

Two students, one from Kansas and one from China, teamed up to make a presentation to the Emporia city commission regarding the importance of rental-housing code enforcement. Both students had an immediate self-interest in the issue because they lived in what they believed to be substandard housing, and they had received little or no response from landlords when they requested repairs. They extensively researched the housing codes in nearby cities. In this case, the students' key allies were themselves: they had been referred to one another when it became clear that they had planned projects on a similar topic. They next identified their target as the elected city commission. Working with the city manager's office to schedule the presentation, they prepared and delivered a report during a commission meeting.

\section{LOCAL GOVERNMENTS ARE RESPONSIVE,}

\section{SCHOOLS NOT SO MUCH}

In their 2009 book, Graham and Hand particularly emphasized the value of making change on campus (Graham and Hand 2009). The idea began in 1974 when Senator Graham was chairing a meeting of the Florida State Senate education committee held at Wolfson Senior High School in Jacksonville. A delegation of students presented their primary school-based concern: bad food in the cafeteria.

Senator Graham became concerned when the students indicated that they had sought redress from the mayor of the city, the county sheriff, and ultimately the state legislature. He concluded that something was wrong in their civics instruction because the students had missed a basic question for effective citizenship: "Who can solve my problem?"

It is ironic that today, most successful projects work with the local city or county government. Change at the campus level, however, can be elusive; many students pursue on-campus projects, but only a few succeed. It is ironic that the very institutions that nurture these civic-action skills can be resistant to their influence. Compared to local governments, universities seem to have additional layers of complexity, including committees that meet infrequently-despite their feedback being required for policy change; the appointment of interim administrators who delay major policy change; and the disappearance of key decision makers from campus for extended periods due to sabbatical, conference- or research-related travel, or seasonal school breaks. By contrast, local officials are either elected, or appointed directly by those who are elected, which results in a responsiveness not always seen in the universities.

\section{It is ironic that today, most successful projects work with the local city or county government. Change at the campus level, however, can be elusive; many students pursue on-campus projects, but only a few succeed.}

Although the students had suggested new codes, city leaders chose instead to pursue more aggressive enforcement of existing ones (Fitch 2012). This recent initiative was influenced by a number of factors other than the students' presentation, but they had an active role in putting the issue on the agenda. Time will tell if the city's response is adequate; if it is not, future students in the same class (many of whom live in rental housing near campus) may tackle the issue again.

Several students completed separate projects calling for better traffic management in local intersections. Many made presentations to Emporia's traffic and safety committee. Their motivation was their own self-interest as commuters who drive regularly through unregulated intersections they believed to be unsafe. After easily identifying their self-interest, they researched the safety benefits of stop signs replacing certain unregulated intersections. Furthermore, each student identified the key decision makers, specifically the traffic and safety committee, which agreed to hear their presentations. Several students practiced their presentations in advance, thereby developing public-speaking skills. They often worked together, enlisting one another as allies. As a result of these student presentations, the city's local leaders committed to the electronic monitoring of traffic flow at several unmarked intersections to evaluate the need for better signage.
Our school problems do not end here. We attempted to adapt this curriculum for high schools but were dissuaded by sympathetic teachers. The three most commonly cited barriers were (1) fear of controversy by administrators and school boards, (2) refusal of school districts to approve any off-campus student travel or projects due to legal liabilities, and (3) teachers who are already exhausted by their time- and grading-intensive advanced placement (AP) classes. As a result, we refocused our efforts to future teachers studying at universities such as Emporia State rather than the high school classes. Our hope is to inspire and educate the teachers who will one day teach those $\mathrm{K}-12$ students.

\section{ONLINE CLASSES}

This curriculum is a good fit with online courses. Many online students take the projects seriously; for example, the project about city water lines described previously was an online project. The curriculum is assignment-driven and self-directed, which is a good fit for the online model. This project-based approach is also a good fit for nontraditional students who frequently take online courses. These students often have life experiences that make for good project topics. For example, many have elementary-school-aged children, and they pursue projects related to school policies or to their children's safety going to and from school. Our approach to the online syllabus features a "bare-bones" 
curriculum: homework from each chapter of the America book plus the final project, along with traditional lessons in how a bill becomes a law (contrasting the United States with parliamentary and mixed systems), rational-choice theory, winner-take-all elections versus proportional representation, and the social contract. This curriculum meets the course objectives listed previously.

Complementary but not identical approaches also are working well at other universities. For example, Emma Humphries of the Bob Graham Center for Public Service at the University of Florida recently developed and piloted an online course in citizenship titled Rethinking Citizenship: Identity, Collaboration and Action. The purpose of this course is to teach the knowledge and skills of engaged citizenship in the twenty-first century and to promote thoughtful student activism. The exclusively online course features no long lectures, no textbook, and no exams. Instead, students complete academic "Reqs" and "Challenges" as well as experiential "Missions," all project-based assignments that allow for creativity, collaborative learning, and student choice of topics.

\section{CONTROVERSY?}

Our curriculum gives no special consideration to "hot-button" social issues, and we caution students who want to take on such projects. For example, students who want to tackle abortion rights (either side of the debate) are advised to switch topics. We remind them that in this class, they learn the skills that they will need to become active on the abortion-rights issue, on their own time, when the class is over. In the meantime, we suggest topics such as those discussed in this article as a better way to "get their political feet wet." difference between "textbook" and "real-world" models of decision making. Our approach offers students a skill set that is vital for civic life and loftier policy goals, as well as careers including education, research, civil service, nonprofit management, and business. Furthermore, this approach builds social capital.

\section{ALTERNATIVES}

An alternative method to the curriculum presented in this article would be a greater emphasis on group work. Strength in numbers can overcome the time and other limitations that prevent many students from ultimate success. Group-based learning often generates concerns about "free riders," but it is possible to monitor this type of behavior in the classroom. Our strategy has been to first encourage individual work to identify project topics about which students are passionate. Later, they are given class time to form groups based on similar project topics and to share ideas. Finally, students write their own individual report about what they contributed to the success or failure of the project, regardless of whether they worked individually or with others. However, we have not pursued true group-based projects due to the free-rider concerns. Others may try for the kind of success that Senator Graham had in Wolfson Senior High School. In fact, the natural grouping of topics makes this approach relatively easy; of their own accord, students often choose to work together on similar projects.

Another alternative is suggested: at a larger university, this curriculum could be taught easily by focusing the main lectures on traditional political science lessons, whereas the "discussion" or "lab" sections led by teaching assistants could emphasize the new curriculum and the way it reinforces the lecture and readingassignment lessons.

\section{Our approach offers students a skill set that is vital for civic life and loftier policy goals, as well as careers including education, research, civil service, nonprofit management, and business. Furthermore, this approach builds social capital.}

Our national politics often are consumed by hot-button issues, but many people see their everyday lives affected as much, or more, by issues such as those discussed in this article. Speed bumps near schools and longer hours of operation at the campus recreation center may not be sexy topics, but many students see them as more relevant to their lives. The project topics also offer a break from the often-divisive politics of the hot-button issues. Some students who state that they "hate politics" may be disgusted by the divisive fights over these issues, and their projects can provide a new perspective.

Rodolfo Espino, as quoted by Hibbing and Theiss-Morse (2002), dismissed the value of such local projects by saying, "it is far easier for a group to get a speed bump installed in a neighborhood than to come up with a nationwide plan for dealing with air pollution." This is true, but we argue that the skill set needed to change public policy is indeed similar in both situations. The best and most gratifying place to start learning these skills is at the local level. Early practice and success internalize these skills, which may be useful later for more complex state and national policy change. Speed bumps and national air-pollution policies both require an appreciation of the different levels of government under the federalist system, as well as persuasive speaking and writing, active listening, ability to hold elected officials accountable for their promises, knowledge of the budgeting process, ability to weigh tradeoffs, and knowing the

\section{RESULTS AND RECOMMENDATIONS}

It is not surprising that our first recommendation is the continued and expanded use of active-citizenship curricula in appropriate political science courses. The student projects and related homework assignments work well in conjunction with more traditional material in political science. We believe that these lessons can be tailored into civic-engagement projects that complement traditional lessons in government and political science. The real-world experience that we have had so far in teaching the curriculum has generally been positive, as have the students' course evaluations.

We remain steadfast in recommending that our curriculum not be limited to university political science majors or "honors" students or that it be an AP project for high school. President Jefferson's mandate was for all citizens, not limiting education to those with preexisting interests in politics, college credit, or good grades. We recall the success of service learning in reaching students who were at risk of becoming high school dropouts, as well as the particular success that some non-honors students have with these projects. We believe this curriculum benefits everyone; however, if only a single group were to be targeted, it should be future teachers.

Finally, many students have incomplete projects, and it is important to ensure that they do not disengage from active citizenship as 
a result. Hibbing and Theiss-Morse noted that Americans who have tried and failed to change government policy can end up with an even lower political efficacy than those who never attempted policy change (Hibbing and Theiss-Morse 2002). The good news is this: students do not report this lowered efficacy, either in the project reports or in the course evaluations. Instead, students tend to take personal responsibility for their incomplete projects, acknowledging that it may well have succeeded if they had done more planning, avoided procrastination, and followed through more aggressively on the policy-making contacts they developed while doing the research.

\section{CONCLUSION: KEEPING OUR DEMOCRACY}

We suggest that the following three principles be incorporated into a new curriculum for appropriate political science courses. First, we recommend that particular attention be given to the education of future teachers at all levels. Second, we promote the use, deliberation, and development of these "learn-by-doing" curricula in undergraduate political science courses, complementing but not replacing the traditional curriculum. Third, we want to reinvolve political scientists in the training of high school teachers and in the development of state and national model curricula for civics instruction.

There are three reasons to effectively teach active citizenship. First, students cannot make informed choices for or against being active citizens unless they have effectively studied what that means. Current civics courses often fail to clear even this first hurdle. Second, even Hibbing and Theiss-Morse acknowledged the large numbers of "stealth democrats": that is, apathetic Americans who become active citizens when the rare occasion calls for it (Hibbing and TheissMorse 2002). When this happens, we want even stealth democrats to participate thoughtfully, fairly, and effectively. Schools do not hold fire drills because there will be a fire every day; rather, they hold them so that students can be effectively prepared. However, there always are "fires" in our democratic system, so we think of our curriculum as a fire drill for democratic participation. Third, effective teaching may influence those "on the fence" about active citizenship, nudging them toward the side of informed participation. Again, we recall the NCCLDE's remarkable finding (a related although not identical idea to our own) that even those students at risk of becoming high school dropouts express an interest in service learning (NCCLDE 2012).

Successive generations of Americans have become increasingly reliant on direct-democratic processes, with greater use of mechanisms such as petition initiatives and party primary elections. However, we are not preparing young citizens to participate meaningfully in democracy. As Peter Schrag noted, the result is that these democratic processes often become not a laboratory of democracy but rather a new forum dominated by political strategists and special-interest groups that often pursue a narrow social or economic self-interest
(Schrag 2004). Yet, despite our ever-increasing need for good civic education, empirical studies show that it has lost ground during the 40 years since Langston and Jennings first sounded the alarm in 1968. Despite the plethora of research in our own discipline that can lead to better citizenship education, too many political scientists still sit on the sidelines. Too often, we fall into the trap of treating what we do in the classroom as a routine, forgetting that what we know and do can build social capital and enrich lives. The success of this curriculum is a wake-up call.

\section{R E F E R E N C E S}

Campbell, Angus, Philip Converse, Warren Miller, and Donald Stokes. 196o. The American Voter. Ann Arbor: University of Michigan Press.

Campbell, David E. 20o8. "Voice in the Classroom: How an Open Classroom Climate Fosters Political Engagement among Adolescents." Political Behavior 30: 437-54.

Dalton, Russell. 2012. The Apartisan American: Dealignment and Changing Electoral Politics. Washington, DC: CQ Press.

Delli Carpini, Michael X., and Scott Keeter. 1997. What Americans Know About Politics and Why It Matters. New Haven, CT: Yale University Press.

Ehman, Lee E. 1980. "The American School in the Political Socialization Process." Review of Educational Research (50): 99-119.

Fitch, Ben. 2012. "Property Enforcement Requires Community Voice." Emporia Gazette, May 1.

Graham, Bob, and Chris Hand. 2009. America: The Owner's Manual, Making Government Work For You. Washington, DC: CQ Press.

Hartocollis, Anemona. 2005. "Who Needs Education Schools?" New York Times, July 21.

Hibbing, John R., and Elizabeth Theiss-Morse. 1996. "Civics Is Not Enough: Teaching Barbarics in K-12." PS: Political Science and Politics (29): 57-62.

. 2002. Stealth Democracy: Americans' Beliefs about How Government Should Work. New York: Cambridge University Press.

Jennings, M. Kent, and Richard G. Niemi. 1974. The Political Character of Adolescence. Princeton, NJ: Princeton University Press.

Kidd, Quentin. 2011. Civic Participation in America. Hampshire, UK: Palrgrave/ Macmillan.

Langston, Kenneth P., and M. Kent Jennings. 1968. "Political Socialization and the High School Civics Curriculum in the United States." American Political Science Review (62): 852-67.

National Conference on Civic Learning and Democratic Engagement (NCCLDE). 2012. "A Crucible Moment: College Learning and Democracy's Future." http://www.ncoc.net/CrucibleMoment. Accessed May 17, 2012.

Niemi, Richard, and Jane Junn. 1998. Civic Education: What Makes Students Learn. New Haven, CT: Yale University Press.

Putnam, Robert D. 2001. Bowling Alone: The Collapse and Revival of American Community. New York: Touchstone/Simon \& Schuster.

Schrag, Peter. 2004. Paradise Lost: California's Experience, America's Future. Berkeley: University of California Press.

Schulz, Wolfram, John Ainley, Julian Frallion, David Kerr, and Bruce Losito. 2010. "Initial Findings from the IEA International Civic and Citizenship Education Study." Amsterdam: International Association for the Evaluation of Educational Achievement. http://iccs.acer.edu.au/uploads/File/Reports/ICCS_10_Initial_ Findings.pdf.

Smith, Eric R. A. N. 1989. The Unchanging American Voter. Berkeley: University of California Press. 


\section{APPENDIX: Rubric for the Final Project}

\section{DEFINING THE PROBLEM}

1. Did you clearly explain how "your problem" was directly related to your self-interest? (Ch. 1)
Poor
Fair
Adequate
Good
Outstanding

2. Did you define your problem in such a way that it was specific? (Ch. 1)
Poor
Fair
Adequate
Good
Outstanding

3. Did you identify possible solutions that were highly specific and could be enacted by state, local, or campus government? (Ch. 1) Poor

Fair

Adequate

Good

Outstanding

\section{SKILLS USED}

4. Was your research on the problem thorough, did it cite credible sources, and was it directly related to the problem and its possible solutions? (Ch. 2)
Poor
Fair
Adequate
Good
Outstanding

5. Did you identify key decision makers BY NAME, explore their respective self-interests, and then effectively target them? (Chs. 3 and 5 )
Poor
Fair
Adequate
Good
Outstanding

6. How thoroughly and effectively did you address the issue of timing (e.g., regarding the budget cycle)? (Ch. 6)
Poor
Fair
Adequate
Good
Outstanding

7. How effectively did you identify allies BY NAME and mobilize them in the pursuit of your goal(s)? (Ch. 7)
Poor
Fair
Adequate
Good
Outstanding

8. Did you use the news media effectively in the pursuit of your project? If not, did you develop a plan to go to the news media in case it should become necessary? Did you (or were you prepared to) target local reporters on relevant beats BY NAME and "pitch" your story to them? (Ch. 8)
Poor
Fair
Adequate
Good
Outstanding

9. Did you self-assess effectively, identifying strengths as well as weaknesses to be overcome in pursuit of your goal? (Ch. 9)
Poor
Fair
Adequate
Good
Outstanding

FINAL OUTCOME

10. Did you achieve your goal? If so, did you clearly show that your own actions contributed to this achievement? If not, did you make substantial progress and develop a plan to "finish the job on your own" after semester's end? (Ch. 10)
Poor
Fair
Adequate
Good
Outstanding

FINAL PROJECT GRADE:

FINAL PROJECT POINTS TOTAL: 